\title{
The Positive Association of Obesity Variants with Adulthood Adiposity Strengthens over an 80-Year Period: A Gene-by-Birth Year Interaction
}

\author{
Ellen W. Demerath ${ }^{a}$ Audrey C. Choh ${ }^{b}$ William Johnson $^{\mathrm{a}, \mathrm{e}}$ Joanne E. Curran $^{\mathrm{d}}$ \\ Miryoung Lee ${ }^{b, c}$ Claire Bellis ${ }^{d}$ Thomas D. Dyer ${ }^{d}$ Stefan A. Czerwinski ${ }^{b}$ \\ John Blangero ${ }^{d}$ Bradford Towne ${ }^{\text {b,c }}$ \\ ${ }^{a}$ Division of Epidemiology and Community Health, School of Public Health, University of Minnesota, Minneapolis, \\ Minn., Departments of ${ }^{b}$ Community Health and ${ }^{c}$ Pediatrics, Boonshoft School of Medicine, Wright State University, \\ Dayton, Ohio, and d Department of Genetics, Texas Biomedical Research Institute, San Antonio, Tex., USA; \\ ${ }^{\mathrm{e}} \mathrm{MRC}$ Unit for Lifelong Health and Ageing, London, UK
}

\section{Key Words}

Gene · Genetic · Heritability · Risk score · Obesity · Body mass index - Adiposity - Waist circumference - Interaction . Gene-by-environment interaction - Secular trend - Single nucleotide polymorphism

\section{Abstract \\ Objective: To test the hypothesis that the statistical effect of obesity-related genetic variants on adulthood adiposity traits depends on birth year. Methods: The study sample in- cluded 907 related, non-Hispanic White participants in the Fels Longitudinal Study, born between 1901 and 1986, and aged 25-64.99 years ( 474 females; 433 males) at the time of measurement. All had both genotype data from which a ge- netic risk score (GRS) composed of 32 well-replicated obesi- ty-related common single nucleotide polymorphisms was created, and phenotype data [including body mass index (BMI), waist circumference, and the sum of four subcutane- ous skinfolds]. Maximum likelihood-based variance compo- nents analysis was used to estimate trait heritabilities, main effects of GRS and birth year, GRS-by-birth year interaction, sex, and age. Results: Positive GRS-by-birth year interaction effects were found for BMI ( $p<0.001)$, waist circumference}

\section{KARGER}

E-Mail karger@karger.com www.karger.com/hhe $(p=0.007)$, and skinfold thickness ( $p<0.007)$. For example, each one-allele increase in GRS was estimated to result in a 0.16 increase in $\mathrm{BMI}$ among males born in 1930 compared to a 0.47 increase among those born in 1970. Conclusions: These novel findings suggest the influence of common obesity susceptibility variants has increased during the obesity epidemic.

(c) 2013 S. Karger AG, Basel

\section{Introduction}

A recent debate published in the British Medical Journal posed the following question: 'Are the causes of obesity primarily environmental?' [1,2]. This seemingly straightforward question belies a common misunderstanding about gene-environment interaction and the obesity epidemic. The nearly 2 -fold increase in obesity prevalence among United States adults from 12.8 to $22.5 \%$ from 1960 to 1988 [3] was certainly environmental in the sense that multiple concurrent nutritional and non-nutritional environmental changes occurred over that period, including changes in food production and food marketing, transport, sleep patterns, and environmental pollutant expo-
(C) 2013 S. Karger AG, Basel

0001-5652/13/0754-0175\$38.00/0
Ellen W. Demerath, $\mathrm{PhD}$

Division of Epidemiology and Community Health, University of Minnesota 1300 South 2nd Street, Suite 300 Minneapolis, MN 55454 (USA)

E-Mail ewd@umn.edu 
sure, among others, that in aggregate resulted in an increased prevalence of obesity [4-6]. Yet, none of these environmental drivers directly affected weight gain at the individual level. Rather, environmental exposures may lead to a particular case of obesity through individual-level responses from the molecular to the behavioral level. Such responses vary between individuals and are strongly influenced by genetic factors. The proportion variance in body mass index (BMI) accounted for by additive genetic effects is estimated to be $40-70 \%$ in virtually every population studied $[7,8]$. For instance, heritability of BMI was the same (approximately 50\%) in families of West African ancestry living in Nigeria, Jamaica, and the United States, despite the large differences in nutrition and environmental conditions between them [9]. The point is that while the environment dictates the prevalence of obesity, genetic variation plays a potent role in determining which particular individuals ultimately will develop it.

Ravussin and Bouchard [10] suggested that within a population, the effect of high genetic susceptibility to obesity (high genetic 'load') is not 'unmasked' unless individuals are exposed to highly obesogenic conditions. To date, the clearest empirical support for this idea is the interaction of physical activity level with variants in the FTO gene [11], the strongest common genetic susceptibility locus for obesity yet discovered [12-14]. The association of FTO variants with adiposity depends on physical activity level, with much weaker associations in individuals with at least moderate physical activity $[11,15]$. In African-Americans, at least in men, a significant association of the FTO variant with BMI, waist circumference (WC), and skinfolds was only observed in those with very low self-reported physical activity, suggesting that only in the absence of virtually any physical activity did the FTO risk allele exert effects on adiposity [16]. These results are for a single gene variant in interaction with a single environmental factor, and more comprehensive genomewide interrogation of gene-by-environment interactions is ongoing [17]. Nonetheless, no single study or group of studies will have high-quality data on all obesity-related environmental exposures, thereby making it difficult to capture the totality of such environmental unveiling of genetic effects.

An approach we have taken is to use the wide range of birth years in Fels Longitudinal Study subjects to investigate birth year as a proxy for individual-level exposure to the numerous known and unknown nutritional and nonnutritional factors that have changed over time, particularly in the last half-century [5], and that may have affected weight gain. The degree to which genetic associa- tions with adiposity vary with birth year (i.e. genetic cohort effects) would be a broad measure of gene-by-environment interaction. For example, we recently used this approach and found a stronger association of a set of common menarche-related genetic variants on peri-pubertal BMI among children in the Fels Longitudinal Study born later in the 20th century than those born earlier in the 20th century [18]. In the present analysis, a number of well-replicated common genetic variants found through genome-wide association studies (GWAS) to be associated with adulthood BMI and obesity were used to represent individual-level genetic susceptibility to elevated adiposity (genetic load). Because the Fels Longitudinal Study is composed of related individuals, the effect of this aggregate set of variants on a variety of adiposity traits, and its interaction with birth year, could be assessed while simultaneously accounting for the shared additive genetic and environmental effects within families. The results presented here provide the first empirical evidence of measured genotype-by-year of birth interaction on adiposity-related traits.

\section{Methods}

Study Design and Subjects

A cross-sectional design was used. Subjects included 907 nonHispanic White adults (477 men, 430 women) in the Fels Longitudinal Study who were born between 1901 and 1986. For each subject, a single study visit was chosen at random among their visits that included complete adiposity data and that occurred between the ages of 25 and 64 years, a period after growth is complete and loss of adipose tissue due to aging is still minimal [19]. The Fels Longitudinal Study has been described in detail elsewhere [20]; briefly, the study began in 1929 as a study of normative child growth and development, and continues today primarily as a study of genetic and environmental determinants of variation in growth and aging traits and the antecedents of common chronic disease. Infants living in Yellow Springs, Ohio, and nearby cities and towns in southwestern Ohio (e.g. Dayton, Ohio), USA, have been enrolled from 1929 onward. Mothers and other family members were also simultaneously enrolled. Participants were not selected on the basis of any pre-existing disease. Up to four generations of participants within a family are being actively followed. The Fels Longitudinal Study, although not a nationally representative study, is nonetheless a normative growth and aging study of a generally healthy and well-nourished population. In fact, infant growth data from the Fels Longitudinal Study were used as the basis for United States infant growth charts until 2000 as they were the most representative longitudinal data then available [21]. There are less than 6 cases of childhood growth stunting in the entire study, and further, markers of maturational timing (age at menarche and age at peak height velocity) were stable in individuals born 1920-1970 $[22,23]$, supporting the assertion that childhood nutritional status was adequate throughout the period of study. 
Subjects selected for the present analysis included all of those with at least one measurement of BMI between ages 25 and 64 years and single nucleotide polymorphism (SNP) genotype data. Comparison of the analysis sample to Fels Longitudinal Study participants with BMI data born in 1901-1986 and aged 25-64 years, but who did not have genetic marker data $(n=574)$, showed that the BMI was 1.36 higher in the analysis sample $(\mathrm{p}<0.001)$.

The 907 participants in the present study were distributed among 148 nuclear and extended families that in total contained 8,043 relative pairings, of which 1,122 pairs were first-degree relatives, 1,260 pairs were second-degree relatives, 746 pairs were third-degree relatives, and 1,260 pairs were less closely related. All protocols and informed consent documents used in the Fels Longitudinal Study were approved by the Wright State University Institutional Review Board.

\section{Phenotype Data}

Weight, stature, WC, hip circumference, and subcutaneous skinfold thickness (biceps, triceps, suprailiac, and subscapular) were measured in triplicate by two trained staff members using standard anthropometric methods and equipment [24]; the average of the triplicate measures was used in the analyses. BMI was calculated as weight $(\mathrm{kg})$ divided by height $(\mathrm{cm})$ squared; a sum of skinfold measures was calculated to represent subcutaneous adiposity, and waist-hip ratio (WHR) and waist-height ratio (WHtR) were calculated as measures of central adiposity.

\section{Genotype Data}

DNA was extracted from stored $\left(-80^{\circ} \mathrm{C}\right)$ buffy coats obtained from fresh whole blood collected via venipuncture using standard procedures. Individuals were genotyped using the genome-wide Illumina 610-Quad Bead-chip array (Applied Biosystems Incorporated, USA) at the Texas Biomedical Research Institute. SimWalk2 mistyping analysis [25-27] was used to determine genotypes that had a high probability of being incorrectly called, and these Mendelian errors were removed by blanking these genotypes. Many of the SNPs included in the obesity genetic risk score (GRS) were not included on the Illumina 610-Quad chip, and so HapMap 2 SNP genotypes were imputed using $\mathrm{MaCH} 1[28,29]$, and were further cleaned using SimWalk 2 [25-27]. Merlin [30] was used to impute any remaining missing genotypes using the pedigree information. The squared correlation between imputed and directly measured genotypes $\left(\mathrm{R}^{2}\right)$ for the SNPs ranged from 0.95 to 1.0 (online suppl. table 1; for all online supplementary material, see www. karger.com/doi/10.1159/000351742).

\section{Genetic Risk Score}

Known common SNPs explain only a small proportion of the phenotypic variance in common disease traits [31]. To minimize the multiple testing problem and to maximize statistical power, a risk score approach was taken [32]. This approach investigates the combined effects of multiple genetic variants in a single variable to represent measured genetic susceptibility, in this case to obesity. Specifically, the variants reported by Speliotes et al. [33] were used to construct the GRS, as this meta-analysis of GWAS studies in over 250,000 individuals provided robust replication for a large number of individual variants influencing BMI in individuals of European ancestry. The 32 SNPs identified in that study were used to calculate the BMI GRS for each subject in the present analysis. For each SNP, the allele that was reported by Speliotes et al. [33] to be associated with greater BMI was considered the risk allele and then the number of risk alleles for each $\operatorname{SNP}(0,1$, or 2$)$ was counted. The GRS was computed as the sum of risk alleles across the 32 SNPs, so that a 1-unit increase corresponded to an increase of 1 risk allele. Details on the SNP rs numbers, closest genes, risk alleles for each SNP, risk allele frequencies, and imputation quality $\mathrm{R}^{2}$ values are provided in online supplementary table 1.

As the individual SNPs vary in effect size, we confirmed that the GRS was a valid representation of the cumulative effect of each SNP. For each trait in the analysis, we tested for heterogeneity of regression effects by fitting a model in which all 32 SNPs were included as covariates but were constrained to have equal effect, and comparing it to a model in which the effect of each SNP was estimated separately. The resulting likelihood ratio test showed no evidence for allele-specific effect heterogeneity for BMI, WC, hip circumference, sum of skinfolds, WHR, or WHtR (d.f. $=31$, all $p>0.25$ ). Second, we tested for heterogeneity of SNP-by-birth year effects by adding those 32 interaction terms to the model as well (d.f. $=62$, all $\mathrm{p}>0.60$ ). These sensitivity analyses validate the critical assumption of the polygenic GRS regarding equal small allelic effects, and the specific assumption of equal allele-by-birth year interaction effects.

\section{Statistical Analysis}

Age- and sex-adjusted adiposity trait means were estimated using general linear regression models to test cohort effects using a derived birth cohort variable that grouped birth years into 5 approximately equal groups: $\leq 1939,1940-1949,1950-1959,1960-$ 1969 , and 1970 or later. Scatter plots of adiposity traits on year of birth, by age group (25-34, 35-44, 45-54, and 55-64 years), were analyzed to examine linearity of the associations. Linear regression analysis was used to examine crude associations between GRS and adiposity traits, without adjustment for relatedness. SAS version 9.2 (SAS, Carey, N.C., USA) was used for these analyses.

The effects of GRS and its interaction with year of birth on adiposity traits were formally modeled using maximum likelihood-based variance components methods implemented in the SOLAR analytic platform [34]. This approach accounts for the non-independence among family members [35], models the additive genetic effects and residual environmental effects as random effects, and models the covariates as fixed effects, with principal components scores added to the model to adjust for population stratification [36]. In the first stage of analysis, we tested sex-byyear of birth and sex-by-GRS interaction effects on all adiposity traits; neither had significant associations with any trait, confirming that sexes could be combined for subsequent analysis. Then, we tested the following covariates in the genetic model: GRS, year of birth, GRS-by-year of birth, sex, the exact age at measurement (age), age ${ }^{2}$, sex-by-age, and sex-by-age ${ }^{2}$. Whereas the descriptive analyses used categorical variables to describe year of birth and GRS relationships, the results indicated linear relationships among the variables, and so year of birth and GRS were entered as continuous variables in the genetic models. Due to residual kurtosis, the adiposity traits were all normalized using direct Gaussian transformation prior to analysis.

Statistical significance of individual covariate effects was evaluated using likelihood ratio tests comparing models where covariate effects were estimated against models where covariate effects were set to zero. Narrow-sense heritability (i.e. the phenotypic variance attributable to additive genetic effects; $\mathrm{h}^{2}=\sigma_{\mathrm{G}}^{2} / \mathrm{P}$, where $\sigma_{\mathrm{G}}^{2}$ is the ad- 
ditive genetic variance and $\sigma_{\mathrm{P}}^{2}$ is the total phenotypic variance) was estimated from the above models and is presented along with the covariate parameter estimates and the proportion of residual variance explained by all covariates. The proportion of the variation explained by the GRS, birth year, and their interaction with one another was calculated for each trait as the difference in total variance explained by covariates in the final model and the total variance explained by covariates in a reduced model in which either GRS and GRS-by-year of birth, or year of birth and GRS-by-year of birth, were not estimated. Finally, to illustrate the interaction effects, parameter estimates from the final models were used to calculate predicted increases in each adiposity trait (untransformed values) per unit GRS at the referent values for the covariates (male, age 45 years) for those born early (1930) and late (1970) in the study.

In summary, the approach was designed to test the hypothesis that particular genetic variants known to influence BMI and related traits had, in aggregate, a significantly different effect on adiposity traits in family members born at different points in time, both before and after the onset of the obesity epidemic, while accounting for relatedness and other shared additive genetic and random environmental effects.

\section{Results}

\section{Main Effect of Birth Year on Adiposity Traits}

A description of the study sample is provided in table 1. The subjects were on average 43.3 years of age at the time of measurement, with mean BMI (26.4) in the low overweight range. Although each birth year group included a wide age range, individuals born in earlier birth year groups were on average older at the time of measurement ( $\mathrm{p}<0.0001$ ). For example, those born before 1940 were on average 51 years of age at measurement, while those born after 1970 were on average 31 years at measurement. Age- and sex-adjusted least squares means for the adiposity traits by 10 -year birth cohort show significant birth year effects on BMI, height, WC, hip circumference, WHR, and WHtR (all p < 0.05) and a trend for sum of skinfolds $(\mathrm{p}=0.14)$. For instance, mean BMI increased from 24.8 in those born before 1940 to 27.9 in those born after $1970(\mathrm{p}<0.0001)$, and mean WC increased from 90.6 to $98.9 \mathrm{~cm}(\mathrm{p}=0.02)$.

To further examine possible confounding by age in the adiposity-by-birth year relationships, we examined scatter plots of each adiposity trait, as shown for WC in figure 1. This illustrates that within each 10-year age group, a positive association of WC was seen with increasing birth year, and within birth year, older age groups had higher WC. The important point is that unlike a cross-sectional study in which all measurements are obtained at the same time (period) (resulting in cohort and age effects being completely confounded with one another), the availabil- ity of observations over the 80 -year period of the Fels Longitudinal Study allows for age and cohort effects to be largely disentangled.

\section{Main Effect of the GRS on Adiposity Traits}

Individual GRS values ranged from 18 to 39 alleles and there were no differences in mean GRS by birth year group (table 1). This indicates that there is no gene-byenvironment correlation or differential survival of individuals with low or high genetic susceptibility to obesity across birth year groups. As would be expected of a polygenic trait risk score, the GRS had a normal distribution, and again as expected, individuals with higher values of the GRS tended to have higher BMI, the effect of which is approximately linear (fig. 2). Of note is that even among individuals with low genetic load (GRS $=18-21$ alleles), mean adulthood BMI was nonetheless over 25. The other adiposity traits also exhibited a linear association with GRS, and the parameter estimates from sex- and age-adjusted regression models (unadjusted for relatedness) for all traits are presented in table 2. All traits other than height $(p=0.12$ ) were positively associated with the GRS in these phenotypic-level regressions.

\section{Interaction of GRS and Birth Year on Adiposity Traits}

Parameter estimates from the best-fitting and most parsimonious genetic models formally testing main effects of GRS, birth year, and their interaction with one another on normalized adiposity traits are presented in table 3. We present results only for traits for which main effects $(p<0.05)$ were observed for birth year, GRS, or both. Inclusion of age ${ }^{2}$ and sex-by-age ${ }^{2}$ terms did not improve the likelihood of the models and were dropped from the final models, but age, sex, and sex-by-age effects remained, in addition to GRS, birth year, and the GRSby-birth year interaction. All traits were significantly heritable $\left(\mathrm{h}^{2}>0.35, \mathrm{p}<0.0001\right)$. There were positive covariate effects of the interaction between GRS and year of birth on weight, BMI, WC, WHtR, and sum of skinfolds ( $p<0.007$ for all). An interaction was not evident for WHR. The residual trait variance explained by the GRS was approximately $1 \%$, that explained by birth year was $0.2-2.4 \%$, and that explained by GRS-by-birth year was $0.2-0.9 \%$. Finally, because the GRS was based on SNPs identified in GWAS of BMI, we examined whether inclusion of BMI in the final models for all other adiposity traits altered their results. The estimates for the effects of GRS and GRS-by-birth year were reduced and no longer statistically significant, showing that all of the effects of the GRS and its interaction with birth year on the oth- 
Fig. 1. Positive association of WC with birth year in 907 Fels Longitudinal Study adults, by age group. Plots show linearity of birth year association within age group, and increasing WC by age group within birth year.

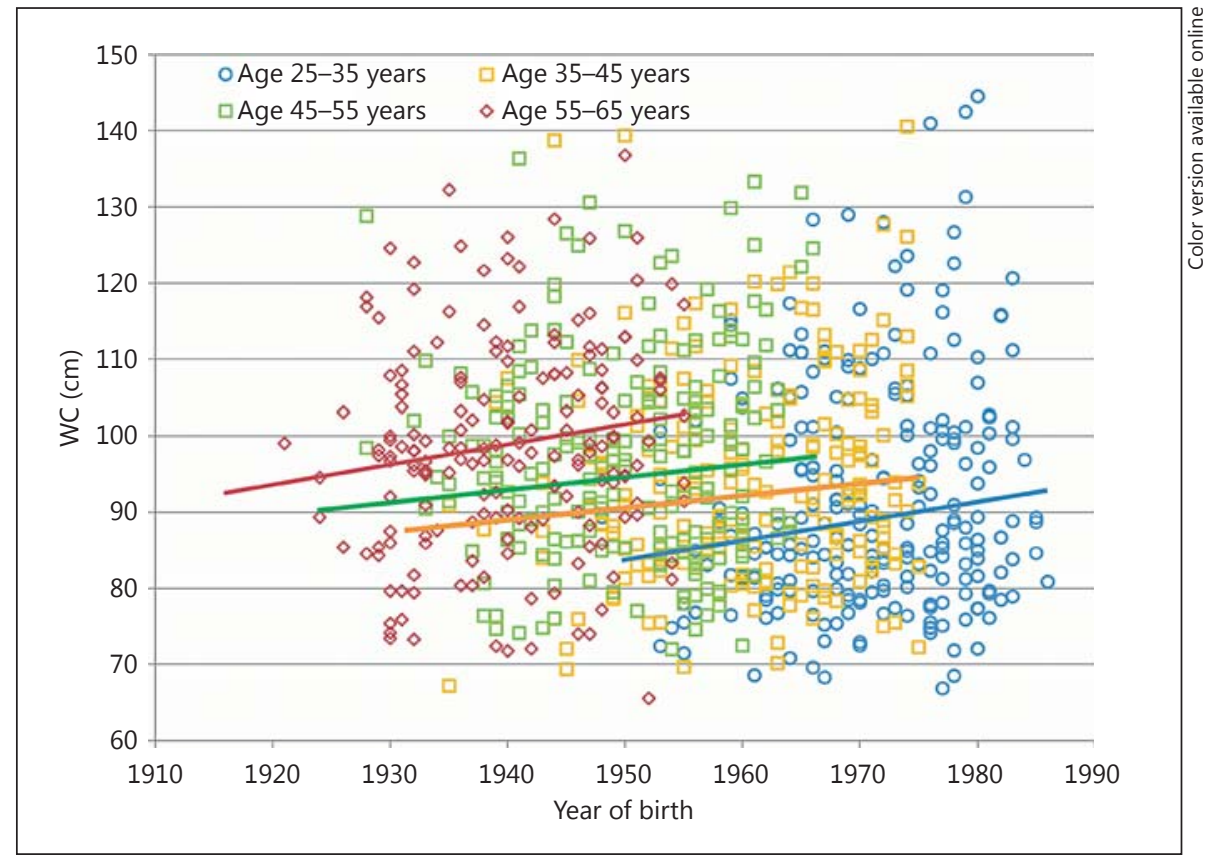

Table 1. Description of the sample data: 907 Fels Longitudinal Study adults aged 25-64 years

\begin{tabular}{|c|c|c|c|c|c|c|c|}
\hline & \multicolumn{6}{|l|}{ Birth year } & \multirow[t]{2}{*}{$\mathrm{p}$ value } \\
\hline & all & $\leq 1939$ & $1940-1949$ & $1950-1959$ & $1960-1969$ & $\geq 1970$ & \\
\hline Female sex, $\%$ & 47.4 & 49.7 & 49.0 & 44.8 & 48.9 & 46.3 & $0.56^{\mathrm{c}}$ \\
\hline Adulthood obesity, n (\%) & $188(20.7)$ & $28(15.8)$ & $34(19.9)$ & $42(21.4)$ & $40(21.9)$ & $44(24.4)$ & $<0.001^{\mathrm{c}}$ \\
\hline Adulthood underweight, n (\%) & $16(1.8)$ & $5(2.8)$ & $2(1.2)$ & $2(1.0)$ & $4(2.2)$ & $3(1.7)$ & $0.44^{\mathrm{c}}$ \\
\hline Birth year ${ }^{a}$ & $\begin{array}{l}1955 \pm 15.0 \\
{[1901-1986]}\end{array}$ & $\begin{array}{l}1931 \pm 7.3 \\
{[1901-1939]}\end{array}$ & $\begin{array}{l}1944.5 \pm 3.0 \\
{[1940-1949]}\end{array}$ & $\begin{array}{l}1954.5 \pm 2.8 \\
{[1950-1959]}\end{array}$ & $\begin{array}{l}1964.4 \pm 3.0 \\
{[1960-1964]}\end{array}$ & $\begin{array}{l}1975.6 \pm 4.2 \\
{[1970-1986]}\end{array}$ & $<0.001^{\mathrm{d}}$ \\
\hline 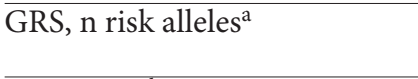 & $\begin{array}{l}28.46 \pm 3.45 \\
{[18-38]}\end{array}$ & $\begin{array}{l}28.9 \pm 3.5 \\
{[19-38]}\end{array}$ & $\begin{array}{l}28.1 \pm 3.6 \\
{[18-38]}\end{array}$ & $\begin{array}{l}28.5 \pm 3.7 \\
{[18-37]}\end{array}$ & $\begin{array}{l}28.5 \pm 3.5 \\
{[29-37]}\end{array}$ & $\begin{array}{l}28.3 \pm 3.4 \\
{[21-39]}\end{array}$ & $0.31^{\mathrm{d}}$ \\
\hline Weight, $\mathrm{kg}^{\mathrm{b}}$ & $\begin{array}{l}78.5 \pm 18.8 \\
{[42.8-176.9]}\end{array}$ & $72.2 \pm 1.4$ & $75.2 \pm 1.38$ & $78.7 \pm 1.2$ & $82.2 \pm 1.3$ & $83.8 \pm 1.5$ & $<0.0001^{\mathrm{d}}$ \\
\hline $\begin{array}{l}\text { WC, } \mathrm{cm}^{\mathrm{b}} \\
(\mathrm{n}=831)\end{array}$ & $\begin{array}{l}95.4 \pm 14.6 \\
{[65-163]}\end{array}$ & $90.6 \pm 1.63$ & $93.1 \pm 1.3$ & $94.8 \pm 0.98$ & $97.4 \pm 1.13$ & $98.9 \pm 1.35$ & $0.02^{\mathrm{d}}$ \\
\hline $\begin{array}{l}\text { Hip circumference, } \mathrm{cm}^{\mathrm{b}} \\
(\mathrm{n}=819)\end{array}$ & $\begin{array}{l}105.0 \pm 10.8 \\
{[80.4-173.6]}\end{array}$ & $102.5 \pm 1.4$ & $104.0 \pm 1.04$ & $104.6 \pm 0.79$ & $106.4 \pm 0.90$ & $106.4 \pm 1.1$ & $0.31^{\mathrm{d}}$ \\
\hline $\begin{array}{l}\text { WHtR } \\
(\mathrm{n}=831)\end{array}$ & $\begin{array}{l}0.55 \pm 0.08 \\
{[0.39-1.04]}\end{array}$ & $0.53 \pm 0.01$ & $0.54 \pm 0.007$ & $0.55 \pm 0.006$ & $0.57 \pm 0.008$ & $0.57 \pm 0.01$ & $0.03^{\mathrm{d}}$ \\
\hline $\begin{array}{l}\text { WHR } \\
(\mathrm{n}=819)\end{array}$ & $\begin{array}{l}0.91 \pm 0.08 \\
{[0.69-1.17]}\end{array}$ & $0.88 \pm 0.008$ & $0.89 \pm 0.006$ & $0.90 \pm 0.004$ & $0.91 \pm 0.005$ & $0.93 \pm 0.006$ & $0.006^{\mathrm{d}}$ \\
\hline $\begin{array}{l}\text { Sum of skinfolds, } \mathrm{mm}^{\mathrm{b}} \\
(\mathrm{n}=775)\end{array}$ & $\begin{array}{l}66.9 \pm 26.6 \\
{[17-165]}\end{array}$ & $62.3 \pm 2.4$ & $67.8 \pm 2.4$ & $65.4 \pm 1.9$ & $70.9 \pm 2.2$ & $66.6 \pm 2.7$ & $0.14^{\mathrm{d}}$ \\
\hline
\end{tabular}

${ }^{a}$ Data are means $\pm \mathrm{SD}$ [range]. ${ }^{\mathrm{b}}$ Data are sex- and age-adjusted means $\pm \mathrm{SE}$ [range]. ${ }^{\mathrm{c}} \chi^{2}$ statistic. ${ }^{\mathrm{d}} \mathrm{F}$ statistic. 
Fig. 2. Frequency distribution for values of a 32-SNP obesity GRS (from Speliotes et al. [33]) in 907 Fels Longitudinal Study adults, overlain by mean and standard error (SE) for BMI within each GRS group.

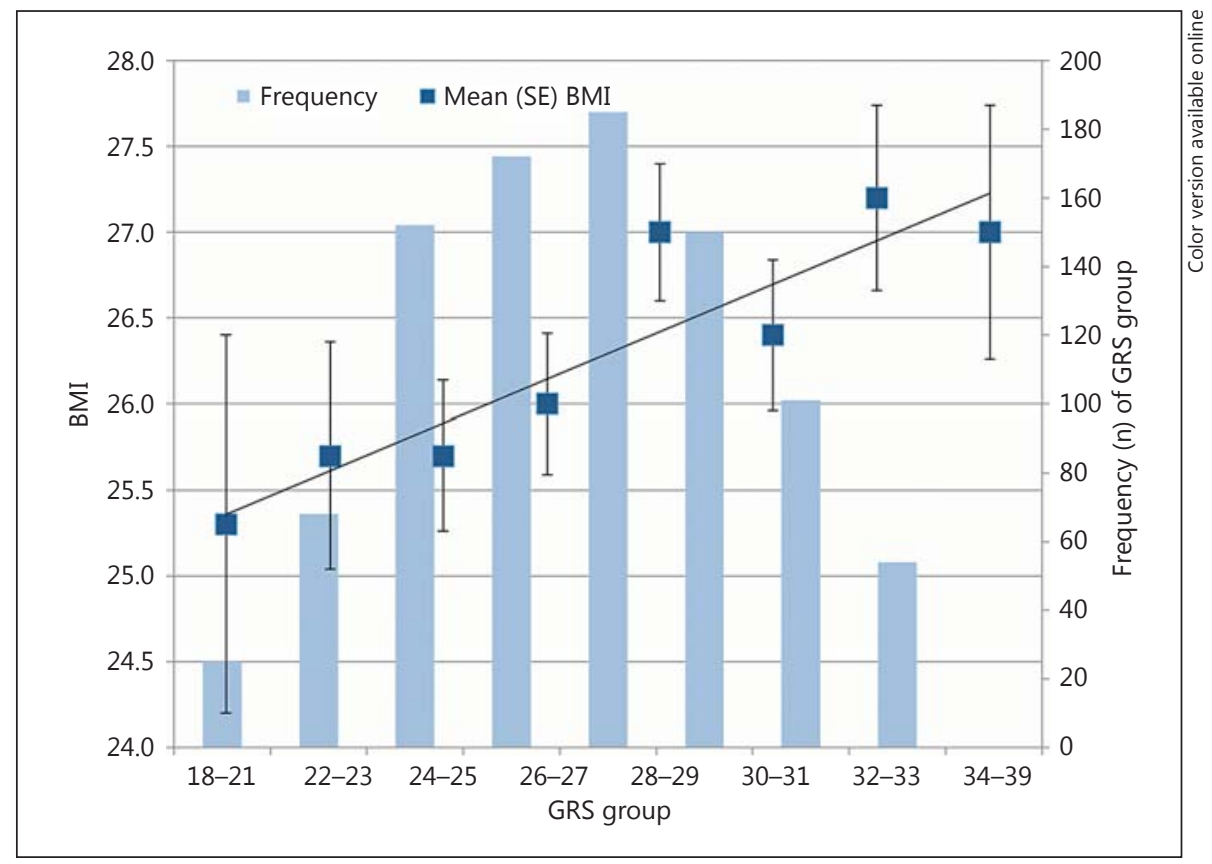

Table 2. Main effect of a GRS for obesity on size and adiposity traits in Fels Longitudinal Study adults aged 25-64 years: phenotypiclevel association

\begin{tabular}{lll}
\hline & $\beta(\mathrm{SE})$ & $\mathrm{p}$ value \\
\hline Weight $(\mathrm{kg} ; \mathrm{n}=907)$ & $0.51(0.16)$ & 0.001 \\
Height $(\mathrm{cm} ; \mathrm{n}=907)$ & $0.10(0.06)$ & 0.115 \\
BMI $(\mathrm{n}=907)$ & $0.14(0.05)$ & 0.007 \\
WC $(\mathrm{cm} ; \mathrm{n}=831)$ & $0.42(0.13)$ & 0.0016 \\
Hip circumference $(\mathrm{cm} ; \mathrm{n}=819)$ & $0.36(0.11)$ & 0.0007 \\
WHtR $(\mathrm{n}=831)$ & $0.002(0.0007)$ & 0.008 \\
WHR $(\mathrm{n}=819)$ & $0.001(0.0005)$ & 0.050 \\
Sum of skinfolds $(\mathrm{mm} ; \mathrm{n}=775)$ & $0.80(0.26)$ & 0.002 \\
\hline
\end{tabular}

Parameter estimates are from linear regression models with the 32-SNP obesity GRS as the independent variable and normalized adiposity traits entered as continuous dependent variables.

Sex and age were included as covariates to adjust the estimates for sex and age variation in the dependent variables.

er adiposity traits are accounted for by their effects on BMI.

As the parameter estimates themselves are difficult to interpret, we used them to compare the model-predicted GRS effect (per allele) on each trait for a 45 -year-old male born in 1930 to a 45-year-old male born in 1970, using the untransformed values of the adiposity variables (table 4). In each case, the per-allele effect of the GRS was approximately 3 times greater for men born in 1970 than for men born in 1930. The GRS-by-sex interaction term was not significant for any of the traits, and similar results were obtained for women.

\section{Discussion}

The present study provides novel evidence that the aggregate effect of common genetic variants on adulthood adiposity depends on year of birth, using data from 907 related, non-Hispanic White participants in the Fels Longitudinal Study born between 1901 and 1986. These individuals were all examined in adulthood, but at different ages, and over an $>80$-year period, allowing for cohort and age effects to be disentangled, and allowing contrasts to be made between individuals growing up and living in markedly different periods, both before and after the onset of the obesity epidemic in the United States. The study provides empirical support for the theory long held by obesity researchers that as the environment becomes more obesogenic, those with higher genetic predisposition for obesity will gain more weight than those with lower genetic predisposition. This concept is illustrated in figure 3, from Ravussin and Bouchard [10] in which 
Table 3. Parameter estimates from the best-fitting and most parsimonious genetic model testing main effects of year of birth, GRS, and their interaction with one another, on adiposity traits in Fels Longitudinal Study adults

\begin{tabular}{|c|c|c|c|c|c|c|}
\hline Subjects, $\mathrm{n}$ & 907 & 907 & 831 & 831 & 819 & 775 \\
\hline Heritability $\left(\mathrm{h}^{2}\right)^{\mathrm{a}}$ & $0.59(0.07)$ & $0.546(0.065)$ & $0.526(0.070)$ & $0.510(0.069)$ & $0.508(0.074)$ & $0.353(0.077)$ \\
\hline $\mathrm{p}$ value & $<0.0001$ & $<0.0001$ & $<0.0001$ & $<0.0001$ & $<0.0001$ & $<0.0001$ \\
\hline $\mathrm{GRS}^{\mathrm{a}}$ & $0.030(0.009)$ & $0.030(0.010)$ & $0.032(0.009)$ & $0.030(0.010)$ & $0.017(0.008)$ & $0.032(0.010)$ \\
\hline Male (referent) & - & - & - & - & - & - \\
\hline Female & $-0.931(0.068)$ & $-0.303(0.060)$ & $-0.629(0.060)$ & $-0.080(0.063)$ & $-1.179(0.050)$ & $0.561(0.066)$ \\
\hline $\mathrm{p}$ value & $<0.001$ & $<0.001$ & $<0.001$ & 0.202 & $<0.001$ & $<0.001$ \\
\hline Birth year (referent: 1929) ${ }^{\mathrm{a}}$ & $0.009(0.005)$ & $0.012(0.002)$ & $0.010(0.005)$ & $0.008(0.005)$ & $0.013(0.004)$ & $0.006(0.004)$ \\
\hline $\mathrm{p}$ value & 0.034 & $<0.001$ & 0.048 & 0.105 & 0.001 & 0.162 \\
\hline Age (referent: 45 years) ${ }^{\mathrm{a}}$ & $0.02(0.006)$ & $0.028(0.004)$ & $0.035(0.006)$ & $0.040(0.007)$ & $0.045(0.005)$ & $0.019(0.006)$ \\
\hline $\mathrm{p}$ value & $<0.001$ & $<0.001$ & 0.007 & 0.007 & 0.170 & 0.007 \\
\hline $\begin{array}{l}\text { Residual variance explained } \\
\text { by all covariates above }\end{array}$ & $25.9 \%$ & $8.8 \%$ & $17.2 \%$ & $9.8 \%$ & $43.3 \%$ & $11.1 \%$ \\
\hline Variance explained by YOB & $0.6 \%$ & $2.4 \%$ & $0.6 \%$ & $0.5 \%$ & $1.0 \%$ & $0.2 \%$ \\
\hline Variance explained by GRS & $0.9 \%$ & $0.9 \%$ & $1.1 \%$ & $0.9 \%$ & $0.2 \%$ & $1.2 \%$ \\
\hline \multicolumn{7}{|l|}{ Variance explained by } \\
\hline GRS-by-YOB interaction & $0.7 \%$ & $0.9 \%$ & $0.7 \%$ & $0.7 \%$ & $0.2 \%$ & $0.8 \%$ \\
\hline
\end{tabular}

All traits were normalized using direct Gaussian transformation prior to analysis; the model shown is the final, reduced model after removal of variance components (age ${ }^{2}$, age $\mathrm{e}^{2}$-by-sex, year of birth-by-sex, and GRS-by-sex) from the full model that did not significantly improve the model fit as determined by comparison of log-likelihoods and the Akaike Information Criterion. ${ }^{a}$ Values are B (SE). YOB $=$ Year of birth.

Table 4. Predicted effects of an obesity GRS on adiposity traits for individuals born in 1930 versus $1970^{\text {a }}$

\begin{tabular}{llll}
\hline \multirow{2}{*}{ Trait } & \multicolumn{2}{l}{$\begin{array}{l}\text { Effect of a 1-allele increase in the GRS } \\
\text { on adiposity traits }\end{array}$} \\
\cline { 2 - 4 } & $\begin{array}{l}\text { birth year: } \\
1930\end{array}$ & $\begin{array}{l}\text { birth year: } \\
1970\end{array}$ & $\begin{array}{l}\text { fold-change } \\
\text { in GRS effect }\end{array}$ \\
\hline Weight, kg & 0.62 & 1.78 & 2.89 \\
BMI & 0.16 & 0.47 & 2.87 \\
WC, cm & 0.47 & 1.24 & 2.64 \\
WHtR & 0.002 & 0.006 & 2.71 \\
Sum of skinfolds, mm & 0.86 & 2.56 & 2.96 \\
\hline
\end{tabular}

${ }^{a}$ Values are calculated from model parameter estimates as in table 3 , assuming sex $=$ male, and age $=45$ years, except adiposity traits were not inverse normalized to improve interpretation.

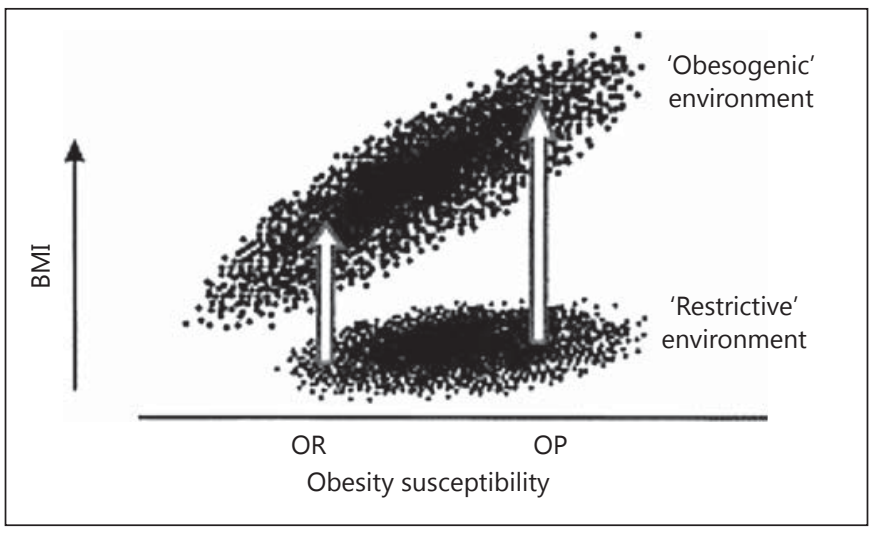

Fig. 3. A classic heuristic model for gene-by-environment interaction on BMI within a genetic population moving from an energyrestrictive environment to an obesogenic environment (adapted from Ravussin and Bouchard [10], used with permission). OR = Obesity-resistant individuals; $\mathrm{OP}=$ obesity-prone individuals. 
the 'restrictive' and 'obesogenic' environments were conceived as points on a spectrum of economic development, from 'traditional' to 'industrialized' economies.

The present study applies this global-level heuristic model to gene-by-environment interaction over the shorter term and in a single, adequately nourished (non-energy restricted) population. The Fels Longitudinal Study includes individuals born in Southwestern Ohio cities and towns, and their descendants, from 1929 to the present. Secular increases in adulthood BMI, WC, subcutaneous skinfolds, and WHR were shown, as they have similarly occurred in United States adults over this period [3]. Mean stature also increased by approximately $2.5 \mathrm{~cm}$ over the period, suggesting that some improvements in childhood health and nutrition may also have occurred. However, the Fels cohort did not experience chronic nutritional stress even early in the study; there were only 6 cases of linear growth stunting in infancy or early childhood, and developmental timing has been quite stable as well [22-23]. The study participants can therefore be characterized, on the whole, as an adequately nourished representation of 'Middle America'. In this light, nutritional and non-nutritional changes that occurred between 1901 and 1986 in the Fels Longitudinal Study are likely far more subtle than those that are now occurring in populations undergoing rapid economic development such as China and India [4, 37]. Nonetheless, a 3 -fold increase in the per-allele effect of the GRS occurred. An implication of the findings is that the influence of common genetic variants on adiposity-related traits would be expected to increase to a greater extent in middle- and lower-income countries experiencing greater changes in the nutritional environment.

Another implication of our study is that cohort effects may explain some of the difficulty in replicating in genetic association studies; for instance, Franks et al. [38] found a significant association of an 11ßHSD1 variant with blood pressure among Pima Indian family members born earlier in that study, as was predicted from animal models, but a much weaker relationship in those born later in the study. Such null results had also been reported for other contemporary human cohort studies. The authors suggested that genetic effects on adulthood blood pressure likely depend somewhat on early life environment, which had changed greatly for the Pima population, and which is notoriously difficult to account for using data collected during study assessment in adult cohorts. This may partially explain why genetic association studies of adults frequently fail to replicate across cohorts [38]. Birth year is a widely available and potentially helpful proxy for early life environmental variation within a population and may aid in understanding the heterogeneity of genetic associations across different studies.

Genetic risk factors for disease are important in part because their effects are potentially cumulative over the entire life course, from conception onwards. The GRS used in this analysis includes SNPs that begin to have significant effects on weight gain in infancy and early childhood [39] and may mediate the association of GRS with adulthood adiposity [40]. It is possible, therefore, that some of the GRS-by-birth year interaction effects we report for adults have operated through alterations in early growth, which has also changed significantly over the 80 years of the Fels Longitudinal Study [41, 42].

To our knowledge, there are no other studies demonstrating a measured genotype-by-birth year interaction effect on adiposity traits, but there are a number of recently published reports that provide support for the findings presented here. A quantitative gene-by-birth year interaction was reported in over 250,000 male siblings and twin pairs conscripted into the Swedish army who were born between 1951 and 1983 [43]. The prevalence of obesity increased from 1 to $5 \%$ of the full sample of 1.5 million conscripts over that period, and in the subset of relative pairs, the total phenotypic variance in BMI increased from 5.7 among those born in 1951 to 9.9 among those born in 1983. Of that total variance, the genetic variance increased from 4.3 to 7.9 , while the unique environmental variance increased only from 1.4 to 2.0 , yielding a significant increase in the heritability. Circumstantial support is also found in the observation that the obesity epidemic was most dramatic at the upper tail of the BMI distribution [44]. Using data from the Behavioral Risk Factor Surveillance system, Sturm [45] reported that the prevalence of adults with a BMI $>30$ approximately doubled between 1985 and 2005, while the prevalence of adults with a BMI $>50$ increased 9 -fold. A recent study in children in the Avon Longitudinal Study of Parents and Children (ALSPAC) used a quantile regression approach to compare the association of an 8-SNP obesity GRS on childhood fat mass adjusted for stature (fat mass index) [46], suggesting that the obesity GRS had greater influence on fat mass index in children in the highest quantiles of adiposity.

It is likely that typical patterns of epigenetic regulation of gene expression are being altered by shifts in the human environment and may be partly responsible for the geneby-year of birth interactions on obesity we reported above [47]. Epigenetic marks are modifiable by environmental factors such as the nutrient content of the diet [48], maternal behavior and stress [49], and environmental pollutants [50]. At this point, few large-scale human studies of differ- 
ential DNA methylation have been conducted, and the environmental determinants of histone modification and other epigenetic modifications are even less well understood. To date, there have been only a handful of human studies examining the relationship of adiposity-related traits to DNA methylation; most have examined methylation near known obesity candidate genes, but epigenomewide association analyses are now also beginning to be published (reviewed in [51]). A number of these have demonstrated association of FTO risk alleles with local CpG methylation variation [52-54]. But, existing studies are generally small $(\mathrm{n}<200)$ and cross-sectional, and therefore have not had sufficient statistical power or appropriate study designs to test the complex interactions among genotype, environment, and DNA methylation variation that likely exist. High-throughput DNA methylation bead chip technology that simultaneously tests methylation levels in hundreds of thousands of sites across the genome [55] are now being used in large cohort studies which may allow such hypotheses to be tested in the near future.

Our study has a number of strengths, foremost being the study design, which incorporates both genotype and adiposity phenotype data on related individuals born over a very long period of time, beginning in the early 20 th century. Limitations of the study include a sample size that was too small to allow analysis of each SNP individually, relying instead on a GRS approach. Our sensitivity analysis indicated that using an unweighted GRS did not bias the results regarding the cumulative effect of the SNPs or their individual interactions with birth year, but nonetheless the results do not shed light on gene-by-birth year interaction effects for any particular SNP. Birth year was used as an omnibus measure of environmental change relevant for obesity; data on specific individual-level behavioral factors, including diet and activity patterns, among other environmental features, were not collected consistently enough over the course of the Fels Longitudinal Study to allow us to attribute the birth year effects to particular sources of variation. Although age and cohort effects could be examined somewhat independently due to the long period over which measurements were taken, it is still true that the most recent cohort was younger on average at the time of measurement than the oldest birth year groups. The expected effect of the negative correlation between age and birth year is to bias the results toward the null hypothesis. This is because in the age range examined, adiposity increases with age, and the positive secular trend in adiposity (as well as the positive interaction between GRS and year of birth) was evident despite the fact that the most recent cohorts had not fully aged into their maximum adiposity at the time of this analysis. The study included individuals from a particular region of the United States who were exclusively of European ancestry, and thus the results may not be applicable to other racial/ethnic groups or other geographic populations. In addition, total body fat mass was not available for most individuals born in the early years of the study, as hydrodensitometry was not integrated into the study protocol until the mid-1960s. However, we did examine anthropometric indicators of adiposity including waist and hip circumference and subcutaneous skinfolds, and examined markers of central adiposity (WHR and WHtR).

\section{Conclusions}

We found a gene-by-environment (birth year) interaction on adiposity traits in adults who grew up and lived in markedly different periods, both before and after the onset of the obesity epidemic in the United States. The study presents to our knowledge the first empirical support for the theory long held by obesity researchers that the influences of genetic variants involved in obesity are 'unmasked' as the environment becomes more obesogenic, even over the relatively short historical period of the past 80 years. An implication of the study is that genetic susceptibility to obesity may be increasingly evident in middle- and lower-income countries experiencing far faster changes in the nutritional environment than were observed here. Epigenetic modification is a possible mechanism underlying the findings requiring further study.

\section{Acknowledgements}

We acknowledge the life-long contributions of the Fels Longitudinal Study participants, and the study staff members, without whose commitment and enthusiasm the study could not exist. In particular, we would like to thank Frances Tyleshevski for her help in the creation of the dataset and the past and present Lifespan Health Research Center data collection team for their contributions. We would also like to thank Dr. Alexander F. Roche, Dr. Roger M. Siervogel, and Dr. W. Cameron Chumlea for their long and fruitful leadership of the Fels Longitudinal Study, which made this unique data source possible. This study was supported by grants from the National Institutes of Health: R01 HD012252 and R01 HD053685.

\section{Disclosure Statement}

The authors have no conflicts of interest. 


\section{References}

1 Wilding J: Are the causes of obesity primarily environmental? Yes. BMJ 2012;345:e5843.

$>2$ Frayling TM: Are the causes of obesity primarily environmental? No. BMJ 2012; 345:e5844.

-3 Flegal KM, Carroll MD, Kuczmarski RJ, Johnson CL: Overweight and obesity in the United States: prevalence and trends, 1960-1994. Int J Obes Relat Metab Disord 1998;22:39-47.

4 Popkin BM, Adair LS, Ng SW: Global nutri- 15 tion transition and the pandemic of obesity in developing countries. Nutr Rev 2012;70:3-21.

$\checkmark 5$ McAllister EJ, Dhurandhar N V, Keith SW, Aronne LJ, Barger J, Baskin M, Benca RM, Biggio J, Boggiano MM, Eisenmann JC, Elobeid M, Fontain KR, Gluckman P, Hanlon EC, Katzmarzyk P, Pietrobeilli A, Redden DT, Ruden DM, Wang C, Waterland RA, Wright SM, Allison DB: Ten putative contributors to the obesity epidemic. Crit Rev Food Sci Nutr 2009;49:868-913.

6 Wells JCK: The evolution of human adiposity and obesity: where did it all go wrong? Dis Model Mech 2012;5:595-607.

7 Stunkard AJ, Harris JR, Pedersen NL, McClearn GE: The body-mass index of twins who have been reared apart. N Engl J Med 1990;322:1483-1487.

$>8$ Allison D, Kaprio J, Korkeila M, Koskenvuo M, Neale M, Hayakawa K: The heritability of body mass index among an international sample of monozygotic twins reared apart. Int J Obes Relat Metab Disord 1996;20:501-506.

$>9$ Luke A, Guo X, Adeyemo AA, Wilks R, Forrester T, Lowe W, Comuzzie AG, Martin LJ, Zhu X, Rotimi CN, Cooper RS: Heritability of obesity-related traits among Nigerians, Jamaicans and US black people. Int J Obes Relat Metab Disord 2001;25:1034-1041.

-10 Ravussin E, Bouchard C: Human genomics and obesity: finding appropriate drug targets. Eur J Pharmacol 2000;410:131-145.

$\checkmark 11$ Kilpelainen T, Qi L, Brage S, Sharp SJ, Sonestedt E, et al: Physical activity attenuates the influence of FTO variants on obesity risk: a meta-analysis of 218,166 adults and 19,268 children. PLoS Med 2011;8:e1001116.

-12 Frayling TM, Timpson NJ, Weedon MN, Zeggini E, Freathy RM, et al: A common variant in the FTO gene is associated with body mass index and predisposes to childhood and adult obesity. Science 2007;316:889-894.

$\checkmark 13$ Scuteri A, Sanna S, Chen WM, Uda M, Albai G, Strait J, Najjar S, Nagaraja R, Orru M, Usala G, Dei M, Lai S, Maschio A, Busonero F, Mulas A, Ehret GB, Fink AA, Weder AB, Cooper RS, Galan P, Chakravarti A, Schlessinger D, Cao A, Lakatta E, Abesasis GR: Genomewide association scan shows genetic variants in the FTO gene are associated with obesityrelated traits. PLoS Genet 2007;3:e115.
14 Dina C, Meyre D, Gallina S, Durand E, Körner A, Jacobson P, Carlsson LM, Kiess W, Vatin V, Lecoeur C, Delphanque J, Valiant E, Pattou F, Ruiz J, Weill J, Levy-Marchai C, Horber F, Potoczna N, Hercberg S, Le Stunff C, Bougneres P, Kovacs P, Marre M, Balkau B, Cauchi S, Chevre JC, Froguel P: Variation in FTO contributes to childhood obesity and severe adult obesity. Nat Gen 2007;39:724-726.

5 Rampersaud E, Pollin TI, Fu M, Shen H, O'Connell JR, Duchame JL, Hines S, Sack P, Naglieri R, Shuldiner AR, Snitker S: Physical activity and the association of common FTO gene variants with body mass index and obesity. Arch Intern Med 2008;168:1791-1797.

16 Demerath EW, Lutsey P, Monda K, Pankow J, Kao L, Bressler J, North K, Folsom A: Interaction of FTO and physical activity level on adiposity in African-American and European-American adults: the ARIC Study. Obesity (Silver Spring) 2011;19:1866-1872.

17 Velez Edwards D, Naj A, Monda K, North K, Neuhouser M, Magvanjav O, Kusimo I, Vitolins MZ, Manson JE, O’Sullivan MJ, Rampersaud E, Edwards TL: Gene-environment interactions and obesity traits among postmenopausal African-American and Hispanic women in the Women's Health Initiative SHARe Study. Hum Genet 2013;132:323336.

18 Johnson W, Choh AC, Curren J, Czerwinski SA, Bellis C, Dyer TD, Blangero J, Towne B, Dmeerath EW: Genetic risk for earlier menarche also influences peri-pubertal body mass index. Am J Phys Anthropol 2013;150: 10-20.

19 Grinker JA, Tucker K, Vokonas PS, Rush D: Body habitus changes among adult males from the normative aging study: relations to aging, smoking history and alcohol intake. Obes Res 1995;3:435-446.

20 Roche A: Growth, Maturation, and Body Composition: The Fels Longitudinal Study, 1929-1991. New York, NY, Cambridge University Press, 1992.

21 Hamill PV, Drizd TA, Johnson CL, Reed RB, Roche AF: NCHS Growth Curves for Children. Birth-18 Years. Series 11, Number 165. DHEW Publication No. (PHS) 78-1650. Hyattsville, MD, 1977.

22 Demerath EW, Li J, Sun SS, Chumlea WC, Remsberg KE, Czerwinski SA, Towne B, Siervogel RM: Fifty-year trends in serial body mass index during adolescence in girls: the Fels Longitudinal Study. Am J Clin Nutr 2004; 80:441-446.

23 Demerath EW, Towne B, Chumlea WC, Sun SS, Czerwinski SA, Remsberg KE, Siervogel $\mathrm{RM}$ : Recent decline in age at menarche: the Fels Longitudinal Study. Am J Hum Biol 2004;16:453-457.

24 Lohman T, Roche A, Martorell R (eds): Anthropometric Standardization Reference Manual. Champaign, Human Kinetics Publishers Inc, 1988.
25 Sobel E, Lange K: Descent graphs in pedigree analysis: applications to haplotyping, location scores, and marker-sharing statistics. Am J Hum Genet 1996;58:1323-1337.

26 Sobel E, Papp JC, Lange K: Detection and integration of genotyping errors in statistical genetics. Am J Hum Genet 2002;70:496-508.

27 Sobel E, Sengul H, Weeks DE: Multipoint estimation of identity-by-descent probabilities at arbitrary positions among marker loci on general pedigrees. Hum Hered 2001;52:121131.

28 Li Y, Willer CJ, Ding J, Scheet P, Abecasis GR: $\mathrm{MaCH}$ : using sequence and genotype to estimate haplotypes and unobserved genotypes. Genet Epidemiol 2010;34:816-834.

29 Li Y, Willer CJ, Sanna S, Abecasis GR: Genotype imputation. Annu Rev Genomics Hum Genet 2009;10:387-406.

-30 Abecasis GR, Cherny SS, Cookson WO, Cardon LR: Merlin - rapid analysis of dense genetic maps using sparse gene flow trees. Nat Genet 2002;30:97-101.

31 Manolio TA, Collins FS, Cox NJ, Goldstein DB, Hindorff LA, Hunter DJ, McCarthy MI, Ramos EM, Cardon LR, Chakravarti A, Cho JH, Guttmacher AE, Kong A, Kruglyak L, Mardis E, Rotimi CN, Slatkin M, Valle D, Whittemore AS, Boehnke M, Clark AG, Eichler EE, Gibson G, Haines JL, Mackay TF, McCarroll SA, Visscher PM: Finding the missing heritability of complex diseases. $\mathrm{Na}$ ture 2009;461:747-753.

-32 Den Hoed M, Ekelund U, Brage S, Grontved A, Zhao JH, Sharp SJ, Ong KK, Wareham JN, Loos RJ: Genetic susceptibility to obesity and related traits in childhood and adolescence. Diabetes 2010;59:2980-2988.

33 Speliotes EK, Willer CJ, Berndt SI, Monda KL, Thorleifsson G, et al: Association analyses of 249,796 individuals reveal 18 new loci associated with body mass index. Nat Genet 2010; 42:937-948.

34 Almasy L, Blangero J: Multipoint quantitative-trait linkage analysis in general pedigrees. Am J Hum Genet 1998;62:1198-1211.

35 Boerwinkle E, Chakraborty R, Sing CF: The use of measured genotype information in the analysis of quantitative phenotypes in man. Ann Hum Genet 1986;50:181-194.

36 Price AL, Patterson NJ, Plenge RM, Weinblatt ME, Shadick NA, Reich D: Principal components analysis corrects for stratification in genome-wide association studies. Nat Genet 2006;38:904-909.

37 Zhai F, Wang H, Du S, He Y, Wang Z, Ge K, Popkin BM: Prospective study on nutrition transition in China. Nutr Rev 2009;67:S56-S61.

38 Franks PW, Knowler WC, Nair S, Koska J, Lee YH, Lindsay RS, Walker BR, Looker HC, Permana PA, Tataranni PA, Hanson RL: Interaction between an 11betaHSD1 gene variant and birth era modifies the risk of hypertension in Pima Indians. Hypertension 2004;44: 681-688. 
39 Elks CE, Loos RJF, Sharp SJ, Langenberg C, Ring SM, Timpson NJ, Ness AR, Davey Smith G, Dunger DB, Wareham NJ, Ong KK: Genetic markers of adult obesity risk are associated with greater early infancy weight gain and growth. PLoS Med 2010;7:e1000284.

-40 Belsky DW, Moffitt TE, Houts R, Bennett GG, Biddle AK, Blumenthal JA, Evans JP, Harrington $\mathrm{H}$, Sugden $\mathrm{K}$, Williams $\mathrm{B}$, Poulton $\mathrm{R}$, Caspi A: Polygenic risk, rapid childhood growth, and the development of obesity. Arch Pediatr Adolesc Med 2012;166:515-521.

41 Johnson W, Choh AC, Soloway LE, Czerwinski SA, Towne B, Demerath EW: Eighty-year trends in infant weight and length growth: the Fels Longitudinal Study. J Pediatr 2012;160: 762-768.

-42 Johnson W, Soloway LE, Erickson D, Choh AC, Lee M, Chumlea WC, Siervogel RM, Czerwinski SA, Towne B, Demerath EW: A changing pattern of childhood BMI growth during the 20th century: $70 \mathrm{y}$ of data from the Fels Longitudinal Study. Am J Clin Nutr 2012; 95:1136-1143.

43 Rokholm B, Silventoinen K, Tynelius P, Gamborg M, Sørensen TI, Rasmussen F: Increasing genetic variance of body mass index during the Swedish obesity epidemic. PloS One 2011;6:e27135.
44 Flegal KM, Troiano RP: Changes in the distribution of body mass index of adults and children in the US population. Int J Obes Relat Metab Disord 2000;24:807-818.

45 Sturm R: Increases in morbid obesity in the USA: 2000-2005. Public Health 2007;121: 492-496.

46 Beyerlein A, Von Kries R, Ness AR, Ong KK: Genetic markers of obesity risk: stronger associations with body composition in overweight compared to normal-weight children. PLoS One 2011;6:e19057.

47 Latham KE, Sapienza C, Engel N: The epigenetic lorax: gene-environment interactions in human health. Epigenomics 2012;4:383-402.

48 Dolinoy DC, Weidman JR, Waterland RA, Jirtle RL: Maternal genistein alters coat color and protects Avy mouse offspring from obesity by modifying the fetal epigenome. Environ Health Perspect 2006;114:567-572.

49 Weaver IC, Cervoni N, Champagne FA, D’Alessio AC, Sharma S, Seckl JR, Dymov S, Szyf M, Meany MJ: Epigenetic programming by maternal behavior. Nat Neurosci 2004;7: 847-854.

50 Armstrong L: Epigenetic control of embryonic stem cell differentiation. Stem Cell Rev 2012;8:67-77.

51 Drong AW, Lindgren CM, McCarthy MI: The genetic and epigenetic basis of type 2 diabetes and obesity. Clin Pharmacol Ther 2012;92: 707-715.
52 Almén MS, Jacobsson JA, Moschonis G, Benedict C, Chrousos GP, Fredriksson R, Schioth HB: Genome wide analysis reveals association of a FTO gene variant with epigenetic changes. Genomics 2012;99:132-137.

53 Bell CG, Finer S, Lindgren CM, Wilson GA, Rakyan VK, Teschendorff AE, Akan P, Stupka E, Down TA, Prokoenko I, Morison IM, Mill J, Pidsley R, International Type 2 Diabetes $1 \mathrm{q}$ Consortium, Deiokuas P, Frayling TM, Hattersley AT, McCarthy MI, Beck S, Hitman GA: Integrated genetic and epigenetic analysis identifies haplotype-specific methylation in the FTO type 2 diabetes and obesity susceptibility locus. PLoS One 2010;5:e14040.

54 Toperoff G, Aran D, Kark JD, Rosenberg M, Dubnikov T, Nissan B, Binstein J, Friedlander Y, Levy-Lahad E, Glaser B, Heilman A: Genome-wide survey reveals predisposing diabetes type 2-related DNA methylation variations in human peripheral blood. Hum Mol Genet 2012;21:371-383.

55 Sandoval J, Heyn H, Moran S, Serra-Musach J, Pujana MA, Bibikova M, Esteller M: Validation of a DNA methylation microarray for $450,000 \mathrm{CpG}$ sites in the human genome. Epigenetics 2011;6:692-702. 